Review Article

Emerging Coronavirus Disease (COVID-19), a pandemic public health emergency with animal linkages: Current status update

Yashpal Singh Malik ${ }^{1 *}$, Shubhankar Sircar ${ }^{1}$, Sudipta Bhat ${ }^{1}$, Vinodhkumar OR $^{2}$, Ruchi

Tiwari $^{3}$, Ranjit Sah", Ali A. Rabaan ${ }^{5}$, Alfonso J. Rodriguez-Morales',7, and Kuldeep

Dhama $^{8 *}$

${ }^{1}$ Division of Biological Standardization, ICAR-Indian Veterinary Research Institute, Izatnagar, Bareilly- 243 122, Uttar Pradesh, India

${ }^{2}$ Division of Epidemiology, ICAR-Indian Veterinary Research Institute, Izatnagar, Bareilly243 122, Uttar Pradesh, India

${ }^{3}$ Department of Veterinary Microbiology and Immunology, College of Veterinary Sciences, UP Pandit Deen Dayal Upadhayay Pashu Chikitsa Vigyan Vishwavidyalay Evum GoAnusandhan Sansthan (DUVASU), Mathura, India -281001

${ }^{4}$ Department of Microbiology, Tribhuvan University Teaching Hospital, Institute of Medicine, Kathmandu, Nepal.

${ }^{5}$ Molecular Diagnostic Laboratory, Johns Hopkins Aramco Healthcare, Dhahran, Saudi Arabia

${ }^{6}$ Public Health and Infection Research Group, Faculty of Health Sciences, Universidad Tecnologica de Pereira, Pereira, Colombia

${ }^{7}$ Grupo de Investigacion Biomedicina, Faculty of Medicine, Fundacion Universitaria Autonoma de las Americas, Pereira, Risaralda, Colombia

${ }^{8}$ Division of Pathology, ICAR-Indian Veterinary Research Institute, Izatnagar, Bareilly- 243 122, Uttar Pradesh, India

\title{
*Corresponding Author(s):
}

Yashpal Singh Malik, PhD (malikyps@gmail.com), Division of Biological Standardization, ICAR-Indian Veterinary Research Institute, Izatnagar 243122, Bareilly, Uttar Pradesh, India

Kuldeep Dhama, PhD ( $\underline{\text { kdhama@rediffmail.com) }}$, Division of Pathology, ICAR-Indian Veterinary Research Institute, Izatnagar, Bareilly, India 


\section{Abstract}

After the appearance of first cases of 'pneumonia of unknown origin' in the Wuhan city, China, during late 2019, the disease progressed fast. Its cause was identified as a novel coronavirus, named provisionally 2019-nCoV. Subsequently, an official name was given as SARS-CoV-2 (Severe Acute Respiratory Syndrome Coronavirus-2) by the International Committee on Taxonomy of Viruses (ICTV) study group. The World Health Organization (WHO) named the Coronavirus disease-2019 as COVID-19. The epidemics of COVID-2019 have been recorded over 113 countries/territories/areas apart from China and filched more than 4292 humans, affecting severely around 1,18,326 cases in a short span. The status of COVID-2019 emergency revised by the WHO within 42 days from Public Health International Emergency (January 30, 2020) to a pandemic (March 11, 2020). Nonetheless, the case fatality rate (CFR) of the current epidemic is on the rise (between 2-4\%), relatively is lower than the previous SARS-CoV (2002/2003) and MERS-CoV (2012) outbreaks. Even though investigations are on its way, the researchers across the globe have assumptions of animal-origin of current SARS-CoV-2. A recent case report provides evidence of mild COVID-2019 infection in a pet dog that acquired COVID-2019 infection from his owner in Hong Kong. The news on travellers associated spread across the globe have also put many countries on alert with the cancellation of tourist visa to all affected countries and postponement of events where international visits were required. A few diagnostic approaches, including quantitative and differential real-time polymerase chain reaction assays, have been recommended for the screening of the individuals at risk. In the absence of any selective vaccine against SARS-CoV-2, re-purposed drugs are advocated in many studies. This article discourse the current worldwide situation of COVID-2019 with information on virus, epidemiology, host, the role of animals, effective diagnosis, therapeutics, preventive and control approaches making people aware on the disease outcomes.

Keywords: Coronavirus, 2019-nCoV, SARS-CoV-2, Animal coronaviruses, COVID-19, Bat coronavirus, Zoonoses, Epidemiology, Transmission, Diagnosis, Antivirals, Prevention and Control 


\section{Introduction}

The commencement of the $21^{\text {st }}$ century has witnessed deadly coronaviruses infection, SARS-CoV and MERS-CoV, during 2002 and 2012. The current decade further ascended with the emergence of the first outbreak of pneumonia of unknown-origin (Lu et al. 2020). Several fatal cases dotted in the Wuhan city, Hubei Province of China during the early weeks of December 2019 (Gao 2020a; Lu et al. 2020). This area was later exclusively identified as the epicentre of the disease and was linked to the spread of the virus across the world. The PUO patients exhibited signs of respiratory illness, coughing, sneezing, chest pain, nausea, vomiting, diarrhoea and a large proportion of affected older people acceded to death. The incubation period varied between 2-24 days. A coronavirus ( $\mathrm{CoV}$ ) was recognized as the cause of PUO and being different from the previous human coronavirus, SARS-CoV, it was named provisionally novel CoV of 2019 (2019-nCoV) by the World Health Organization (WHO) and CoV-associated diseases as "COVID-19" (Du Toit 2020; Gralinski and Menachery 2020). Subsequently, the International Committee on Taxonomy of Viruses (ICTV) proposed its name as Severe Acute Respiratory Syndrome-Coronavirus-2 (SARSCoV-2) (Gorbalenya 2020). The current COVID-19 epidemic has turmoil in the global economy affecting the trade of goods and tourism in the past 30 days (Ayittey et al. 2020).

As on March 11, the COVID-19 has disseminated in more than 114 countries of the world affecting 118,326 persons with 4292 deaths. In China alone, SARS-CoV-2 has affected more than 80955 people and 3162 deaths, where confirmed cases and deaths are maximum from Hubei province, the epicentre of the outbreak (67773 cases and 3046 deaths). The disease spread is rapid and has claimed maximum deaths in Italy (631), Iran (291), and Republic of Korea (60), making Risk Assessment of disease to Very High level by the WHO for all affected regions including China. Furthermore, the WHO on January 30, 2020, declared COVID-2019 as "Public Health Emergency of International Concern" (Du Toit 2020; Habibzadeh and Stoneman 2020; Liu et al. 2020a; Wood 2020) and on March 11, 2020, its status was amended to pandemic. 


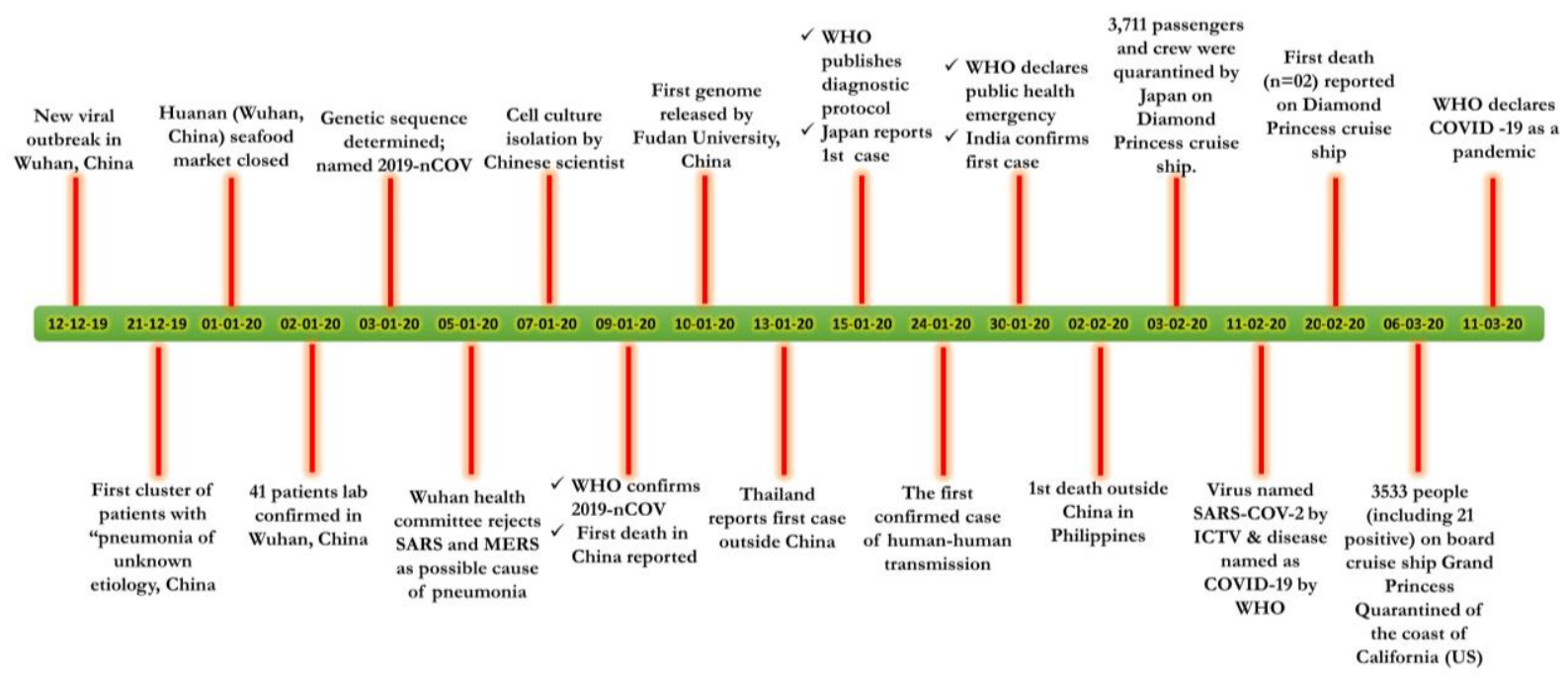

Figure 1: Timeline depicting significant events in due course of the current SARS-CoV2/COVID-19 outbreak.

As the first cases of the disease occurred near the Wuhan Seafood Market (China), where the consumption of live animals is savoured, the disease spread at the prime-face was linked with animal hosts. Starting from December 2019 wherein new cases of "pneumonia" like disease emerged in Wuhan, China followed by confirmation of Chinese Health committee and WHO that a novel coronavirus is a cause of severe respiratory illness among the patients (Fig 1). In January 2020, several other countries in Europe, Asia, and the Americas reported similar cases of novel coronavirus following which WHO declared it as a public health emergency. Scientists all over the world started unravelling the genome and successively provided data for SARS-CoV-2 outbreaks worldwide. Apart from several countries and regions affected by this outbreak, cases were also reported from cruise ships being quarantined off the coast in Japan (Diamond Princes) and the USA (Grand Princess) (Fig 1). On March 11, 2020, WHO declared the COVID-19 outbreak as a global pandemic with SARS-CoV-2 claiming around 4292 lives in 114 countries worldwide (Fig 1).

A controverted report suggesting snake as the source of infection was precluded, as it was based on codon usage studies, but several other reports document bats and pangolins as the primary source of SARS-CoV-2 emergence. The assumption is based primarily on higher genomic sequence similarity of COVID-2019 virus with bat or pangolin origin CoVs. The state-of-art virus detection assays, including qRT-PCR and rapid sequencing-based methods, provided the feasibility of accurate and fast confirmation. As of now, no suitable prophylactic or therapeutics is found effective against the COVID-2019. This review primarily presents the current situation of COVID-2019/SARS-CoV-2 with a focus on the virus, epidemiology, 
transmission, details on coronaviruses affecting animals, and prevention and control measures useful in curtailing the spread of disease.

\section{Coronavirus, genome and classification}

Coronaviruses $(\mathrm{CoV})$ are a member of a diverse group of RNA viruses comprised of a large genome size varying between 26 to $32 \mathrm{~kb}$. The viral genome is linear and monopartite with a positive sense ssRNA genome. The linear RNA genome of CoVs is capped and polyadenylated. The 5' end of the $\mathrm{CoV}$ genome encodes replicase gene which contains two large open reading frames (ORFs), ORF1a and ORF1b. They encompass around two-third or $\sim 20 \mathrm{~kb}$ of the genome. Replicase gene translates two large polyproteins, ppla and pplab. The polyprotein pp1ab is expressed as a result of the translational frameshift between ORF1a and ORF1ab. The replicase polyproteins are further cleaved into 16 proteins which include proteins related to enzymatic activities, protease activities, polymerases and helicases which fuses with a zinc finger complex at the $\mathrm{N}$-terminus and a $\mathrm{Zn}$-ribbon-containing papain-like proteinase. The genome further consists of structural proteins spike (S), envelope (E), membrane $(\mathrm{M})$, and nucleocapsid $(\mathrm{N})$, encoded by ORF at 3' end. Apart from the conventional genome replication, the CoV replicase genome complex mediates the synthesis of a subgenomic (Sg) mRNAs to express all ORFs downstream ORF1b. The CoVs also express few proteins which usually encodes accessory non-structural proteins. Few studies suggested their role in virus-host interactions and also performed certain essential functions. They have a unique mechanism of replication which renders with an ability to undergo mutation and recombination, which enables them to evade the host species barrier.

The newly identified 2019-nCoV/SARS-CoV-2 is a member of order Nidovirales, family Coronaviridae and sub-family Orthocoronavirinae. The subfamily Orthocoronavirinae is further divided into four genera, namely Alphacoronavirus, Betacoronavirus, Gammacoronavirus, and Deltacoronavirus (de Groot et al. 2012). Alphacoronaviruses and Betacoronaviruses are responsible for infection in mammals causing respiratory and enteric diseases in humans and animals. A wide variation in the genome size is seen among all the four genera of Coronaviridae which ranges from 27 to $29 \mathrm{~kb}, 26$ to 32 $\mathrm{kb}, 27$ to $32 \mathrm{~kb}$, and 26 to $26.5 \mathrm{~kb}$ for Alphacoronavirus, Betacoronavirus, Gammacoronavirus, and Deltacoronavirus, respectively. There are six known strains of coronaviruses, causing mild to severe respiratory illness in humans (Su et al. 2016). The strains are from Alphacoronavirus (hCoV-229E and hCoVNL63) and Betacoronaviruses (hCoV-OC43 and hCoV-HKU1), Severe Acute Respiratory Syndrome (SARS)-CoV in Betacoronavirus group B. The Middle East Respiratory Syndrome (MERS-CoV) in 
Betacoronavirus group C. Betacoronaviruses are further subdivided into five subgenera, namely Embecovirus, Hibecovirus, Merbecovirus, Nobecovirus and Serbecovirus. Based on replicase phylogenetic analysis, group $1 \mathrm{CoVs}$ which includes the hCoV-229E also includes other animal infecting viruses like Transmissible Gastroenteritis Virus (TGEV) and Porcine Epidemic Diarrhoea Virus (PEDV). Similarly, the SARS-CoV falls in the group 2 where animal origin mouse hepatitis virus and bovine coronaviruses are found.

The recent 2019-nCoV or SARS-CoV-2 is a member of genus Betacoronavirus in the subgenus Sarbecovirus. The SARS-CoV and MERS-CoVs are quite distant at genomic levels to current 2019-nCoV but are part of the Betacoronavirus genus. The SARS-CoV-2 shows lower similarity (50-51.8\%) with MERS-CoV and similarity is near to $79 \%$ with SARS-CoV (Malik et al. 2020).

\section{SARS-CoV-2/COVID-2019 Epidemiology}

A novel coronavirus (2019-nCoV), emerged in Wuhan, China, at the end of 2019. Epidemiologically, the earliest cases were linked to Jianghan, Wuhan and possibly be infected through zoonotic or environmental exposures (WHO 2003) and the epicentre of the outbreak was Huanan seafood market. A few reports on 2019-nCoV suggests the possible spread of the virus by Chinese beluga fish or snakes or bats or pangolins. The 2019-nCoV infection in humans is possibly a species jump of the virus. The researchers noticed no epidemiological links between patient zero and later infections. However, the majority of the initial cases had direct exposure to the Wuhan animal market. It is claimed that the patient zero possibly carried the infection to the market, rather than catching the virus at the market. Epidemiologically, the cases outside China initially occurred amongst the travellers from China and those who had contact with travellers from China (WHO 2003).

As on January 20, 2020, only 282 cases restricted to China, Republic of Korea, Japan and Thailand were infected with 2019-nCoV. However, the virus has spread its tentacles rapidly, and as on March 11, 2020, more than 1,10,000 individuals were infected in 113 countries of which $>60 \%$ of the cases are from mainland China. Other countries from where major confirmed cases were reported to include South Korea, Italy, Iran, and Japan. According to recent reports, the case fatality in China has decreased, and more than $70 \%$ of infected people are recovered. The preliminary data suggest that age has an inverse relationship with morbidity and mortality associated with COVID-19 infection.

\section{South-East Asia}


In this region, the cases were mainly by foreign travellers. The worst affected countries in this region are Thailand and India, where the local transmission of 2019-nCoV has also seen. India reported its first death due to COVID-19 on March 12, 2020. A Hong Kong person, who travelled for five days on Diamond Princess from Yokohama on January 20, was the source of infection to other persons on Deck and he disembarked in Hong Kong after five days of travel, tested positive for SARS-CoV-2 infection on February 1, six days after leaving the ship. In Diamond Prince's ship, there were 2,666 guests and 1,045 crew members of which 696 were infected, and seven persons have died due to COVID-19.

\section{Europe}

In this region, as on March 11, 2020, Italy is the worst affected country with 10149 confirmed positive cases with 631 moralities (Figure 2). According to the reports of WHO, the case fatality rate in Italy is comparatively higher $(6.2 \%)$ than other parts of the world. The 2019-nCoV after entering into Italy through Chinese tourists spread fast by local transmission. Currently, Italy has the highest number of coronavirus cases in Europe and the second-highest in the world, next to China. In Italy, the local spread is mainly of communal transmission.

\section{Region of the Americas}

In this region, the main countries reported COVID-19 positives are United States of America, Canada, Brazil and Ecuador. The Grand Princess Cruise ship off the coast of California, with 3,500 travellers onboard reported 21 confirmed positive cases of COVID-19.

\section{Middle East Region}

Iran has the highest number of confirmed positives and moralities in this region. The neighbouring of Iran such as Kuwait, Bahrain, Iraq and the United Arab Emirates also reported higher cases in this region. The Nile Cruise ship docked in Egyptian international waters with over 150 tourists reported 45 positives.

\section{Western Pacific Western Pacific}

The Republic of Korea, which is a neighbouring country to hotspot China, has been affected severely with COVID-19. In this region, the infection spreads by local transmission. As on March 11, 2020, the total number of confirmed positive cases was 7755 with 60 deaths (Figure 2).

\section{Transmission, case fatality rate and risk groups}


The human-to-human transmission of SARS-CoV-2 mainly occurs through large droplets, where the risk confines up to $\sim 6$ feet from the COVID-19 affected patient. For curtailing such virus transmission (large droplets) use of a standard surgical-style mask is advised. As of now, airborne transmission of SARS-CoV-2, where for a more extended period the smaller droplets remain aloft in the air, is under investigation. Moreover, the transmission of SARS-CoV-2 from the asymptomatic patients remains a more critical area of consideration as the virus transmission could occur even in the absence of any clinical symptoms. In another situation, the patient in a carrier stage (after clinical recovery) may also shed virus and as reported the recovered patients usually may carry a low viral load with a comparatively lower risk of virus transmission. There is a further need to investigate the role of these convalesced patients in maintaining or transmitting the virus. The fomite-to-face (contact transmission) mode sometimes goes unnoticed, though is enormously significant. The virus could be expelled during coughing and sputum, nasal secretions, stool, saliva, urine, and blood. Thus, in several ways, the infected patient could shed virus into the environment. The virus could persist on fomites in the environment for weeks together. Therefore from this spool of infected material, one can pick up the virus and initiate the event of the next virus infection cycle. It is also hypothesised that the faecal-oral route may also play a role. The first human-to-animal transmission of SARS-CoV-2 is reported in a pet dog of a COVID-19 infected patient in Hong Kong.

The global case fatality rate of COVID-19 is $3.4 \%$. The attack and case fatality rate in an age of fewer than 18 years are relatively low. However, people aged over 50 years and with chronic conditions such as hypertension, diabetes, cardiovascular disease, chronic respiratory disease and cancer have a higher risk. The highest risk group is in above 80 years of people with a case fatality rate of $21.9 \%$ (WHO 2003; Chen 2020; Munster et al. 2020). The sex-wise case fatality rate of COVID-19 of China showed that males are more prone to infection than females because of the smoking habits of a Chinese male.

(Li et al. 2020b) estimated that the mean incubation period of infection with SARSCoV-2 was 5.2 days (95\% CI, 4.1-7.0), with the majority of the cases showing symptoms within 12.5 days of exposure, justify 14 days of quarantine. However, recent reports suggest that more than 14 days incubation period was observed in exposed persons recommending a double quarantine period of 28 days. Recent epidemiological analysis, indicate that the exposed person may act as a source of infection to others during the incubation period. According to the WHO the estimated reproductive number $\left(\mathrm{R}_{0}\right)$ to be 2.2 (95\% CI, 1.4-3.9); however, have determined an $\mathrm{R}_{0}$ between 3.6 and 4.0, and between 2.24 to 3.58 and 7.4 days (95\% CI, 4.2-14), respectively (Zhao et al. 2020). 


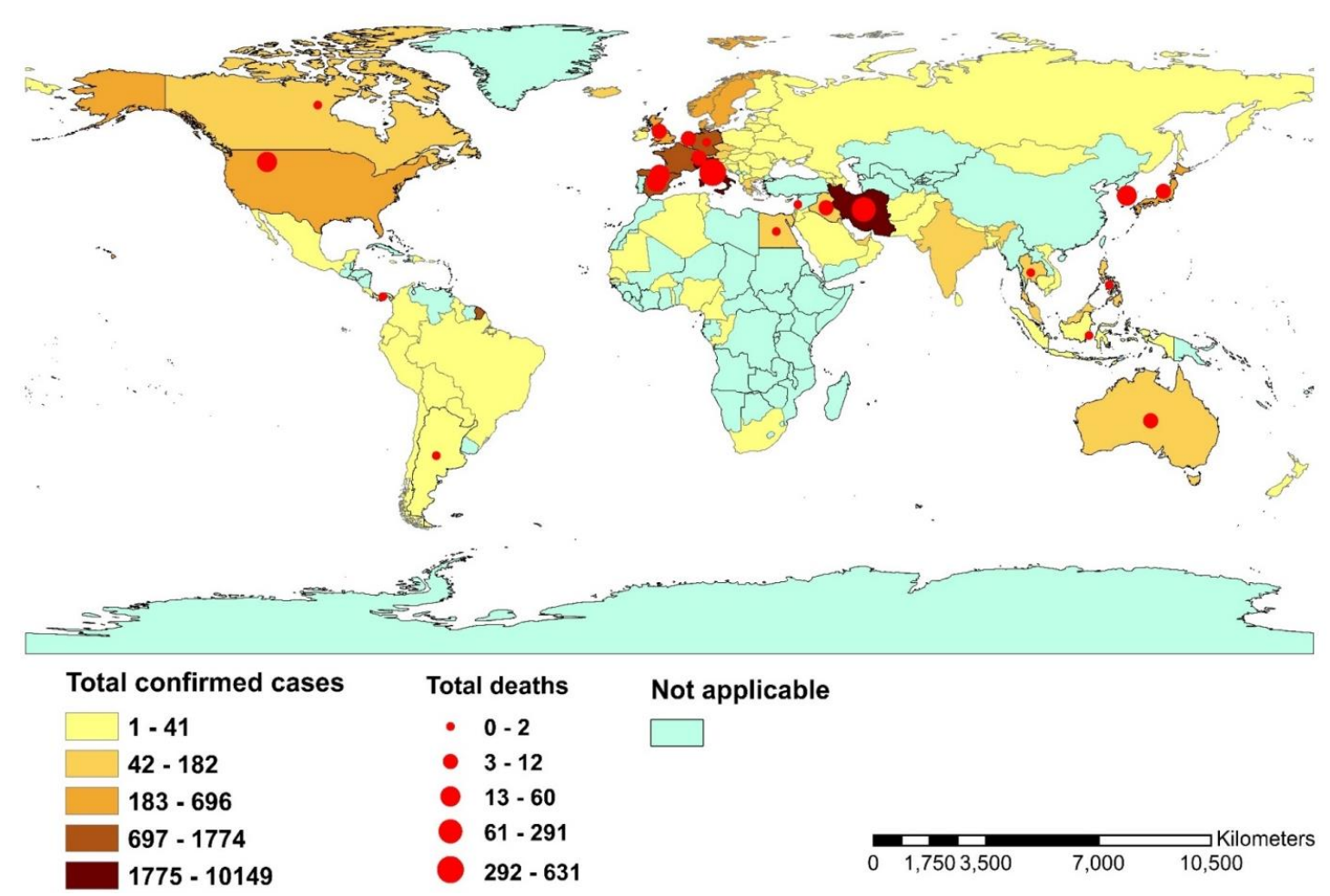

Figure 2: Countries, territories or areas outside China with reported laboratory-confirmed COVID-19 cases and deaths. Data as of 11 March 2020.

\section{Indian Scenario}

On account of emerging cases, India prepared an evacuation plan for the Indian nationals stranded in the hotspot Wuhan. It airlifted 767 people, including people from Nepal, Sri Lanka and the Maldives in two phases. India has also evacuated Indian nationals from Iran. The virus spread in the country has primarily occurred due to foreign travellers or travel. The first positive cases were reported during February 2020 in Kerala from the students travelled from Wuhan city, China. However, there were no secondary cases reported from the Kerala positive persons. Later, the positive cases in India included a Delhi dweller who returned from Italy and a man from Telangana who returned from Dubai. The other positive cases are Italian tourists and their tour guide who was detected positive in Rajasthan. As on March 11, 2020, India reported 76 confirmed positive cases, with one mortality of an older adult in Karnataka who has a recent history of travel to Saudi Arabia. The COVID-19 cases in India comprise both foreign national $(n=17)$ as well as Indian nationals $(n=59)$ having travel history to affected countries after that locally transmitting the virus to other people in contact (Fig 3). 


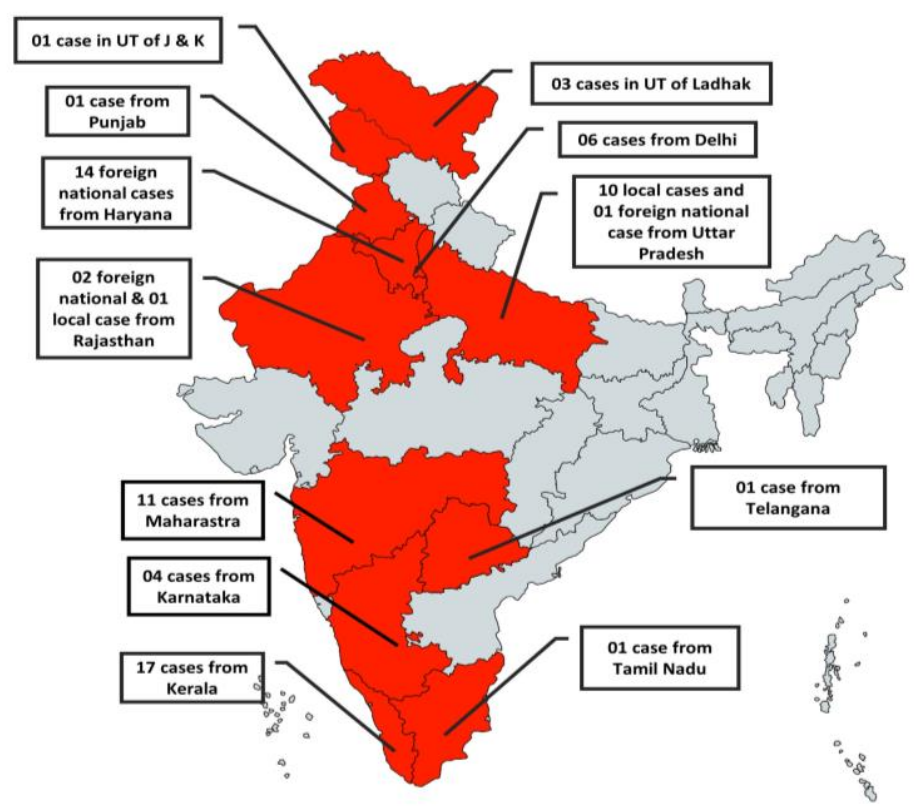

Figure 3: State \& union territories with COVID-19 confirmed cases in India as on March 12, 2020. The first case of SARS-CoV-2/COVID-19 reported in India on January 30, 2020. The list includes ten states and two union territories having 56 Indian national and 17 foreign national confirmed cases.

The Government of India has issued travel restrictions and suspended visa of Iranian, Italian, Japanese and South Korean nationals. Lately, tourist visa for all citizens kept on hold until $15^{\text {th }}$ April 2020. The travel advisory is issued not to travel the worst gaffed countries. In all airports and ports, screening has been in place. The health ministry has also advised observing good personal hygiene, regular monitoring of health, frequent handwashing with soap and water or use of alcohol-based hand sanitizer. Advisory has been issued to follow respiratory etiquettes, to avoid touching your eyes, nose and mouth to avoid close contact with people who are unwell or showing symptoms of illness, to wear a mask if you have symptoms such as cough, fever or difficulty in breathing and to contact a doctor immediately if cough, fever or problem in breathing arises. For information dissemination and help regarding COVID-19 infection, the helpline has been launched. The India based company Serum Institute of India and Codagenix, a US-based firm have entered in a collaboration to develop a viral deoptimized live-attenuated vaccine against the SARS-CoV-2. The vaccine is proposed to provide many advantages, including provoking the host immune response to multiple antigens of the virus (SerumInstitute 2020).

\section{Coronaviruses Host Range}

The CoVs have breached host-species restriction twice in the past. The first incident was for SARS seen in 2002/2003 in humans and virus-origin was linked with bats, and later the second time it occurred in the form of MERS, where it had been linked with dromedary 
camels in the Middle-east countries. The SARS-CoV-2 also appears to have crossed the hostspecies barrier, making CoVs species jumping phenomenon a standard feature. The virus genomic configuration, stability of several replication-associated genes/enzymes, higher mutation rates being RNA virus lacking proofreading features are assumed as the reason behind the emergence of novel CoVs that infects and maintain in several host species (Su et al. 2016). The significant role in the host-range expansion is plated by the outer surface glycoprotein spike gene where a mutation in the Receptor Binding Domain region helps to adapt virus to host species including animals or humans (Chen 2020; Patel and Jernigan 2020).

\section{Coronaviruses infecting animals}

The CoVs are associated with respiratory and enteric illness and usually of mild infections with marginal mortality (Salata et al. 2019; Ji et al. 2020; Li et al. 2020b). Infections due to CoVs have been observed in humans and several farm animals, companion animals, laboratory animals, bats, marine whales, and wild animals. The viruses under Alphacoronavirus and Betacoronavirus genera usually infect bats and other mammals, while viruses under Gammacoronavirus and Deltacoronavirus infects poultry, pigs, fish, and mammals (Woo et al. 2012b; Hu et al. 2017; Cui et al. 2019). Several reports confirm that several avian and mammalian animal species like bovine, equine, porcine, canine, lapine, camelids, avian, rodents, ferrets, mink, bats, snake, frogs, marmots, hedgehogs (Erinaceus europaeus), Malayan or Javan or Sunda pangolin (Manis javanica) serve as carrier/ reservoirs (WHO 2003; Dhama et al. 2014a; Dhama et al. 2015; Monchatre-Leroy et al. 2017; Ji et al. 2020; Xu 2020). Coronaviruses affect several animal hosts and belong to a different genus in Coronavirudae family (Figure 4). Species-wise coronaviruses are detailed. 


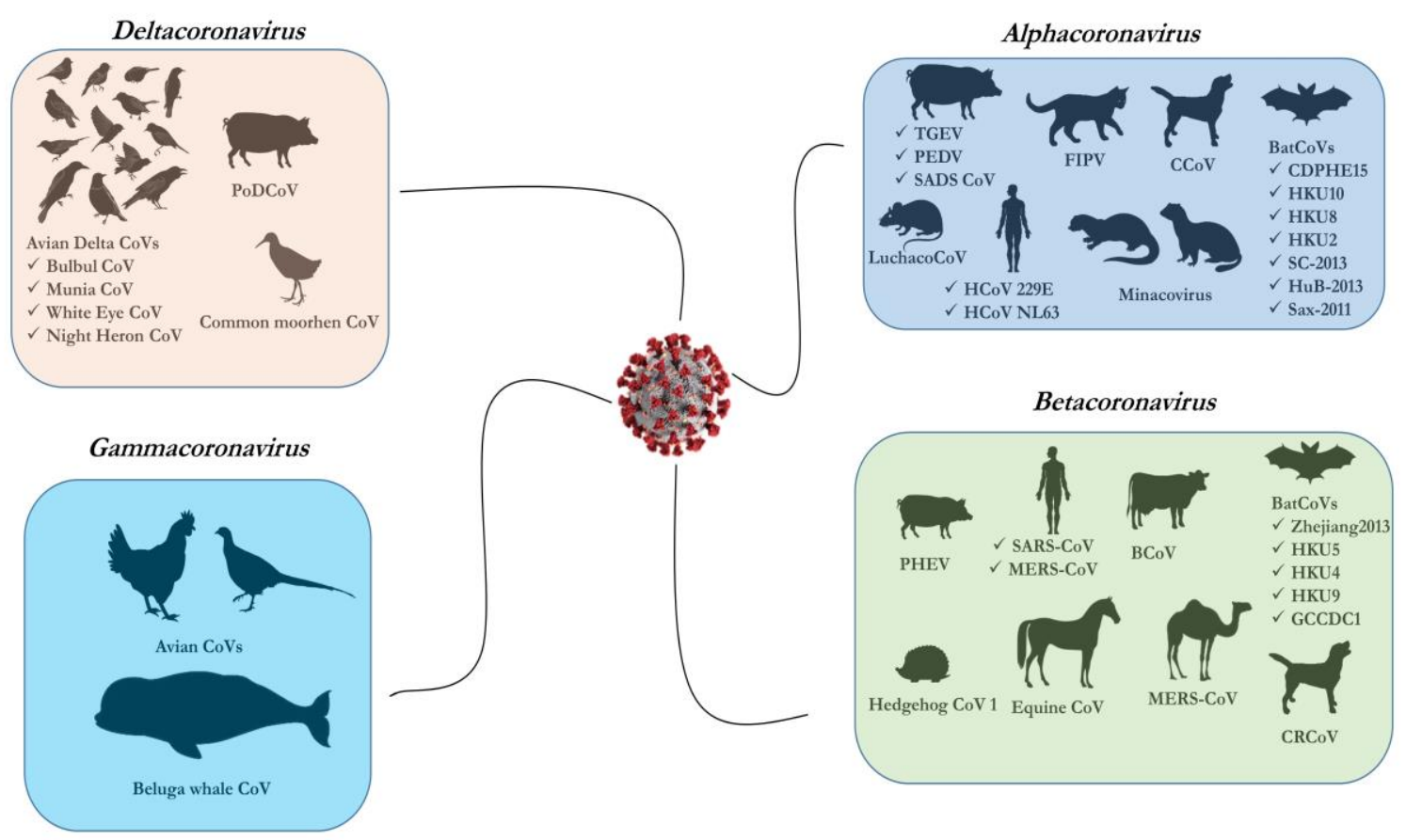

Figure 4: Depiction of different coronaviruses under four genuses (Alphacoronavirus, Betacoronavirus, Gammacoronavirus, and Deltacoronavirus) found in a diverse group of mammalian and avian species.

\section{i. Avian coronaviruses}

The Infectious Bronchitis Virus (IBV), a member of the Gammacoronavirus, causes sizeable economic loss in poultry industry through respiratory illness, urinary tract infection, and reproductive disturbances (Dhama et al. 2014b). The Avian Infectious Bronchitis (AIB) is among the most common viral diseases with significant mortality and morbidity, causing substantial economic losses in the poultry industry worldwide (Cavanagh 2007). AIB was first described in 1931 from the United States, North Dakota (Schalk 1931). Nonetheless, IBV infects mainly chickens of all ages; the younger population is more susceptibility where high mortality is recorded. Furthermore, several IBV-like viruses are documented from pheasants, turkeys and guinea fowls (Weiss and Navas-Martin 2005). AIB spreads through mechanical transmission, including faecal-oral and airborne routes (inhalation and ingestion). The virus targets the respiratory tract of its natural host (Chicken), causing severe respiratory symptoms characterized by gasping, tracheal rales, coughing, nasal exudates, sneezing, respiratory distress, wet eyes and occasionally, swollen sinuses (Weiss and Navas-Martin 2005). Additionally, the virus also affects the digestive tract, reproductive tract and urogenital tract, results in proventriculitis, salpingitis, egg-drop syndrome and nephritis (Fan et al. 2018). The virus replicates in high titre in the ciliated epithelial cells of the respiratory tracts. Mucosal thickening of the upper and lower respiratory tract is the main gross pathological 
findings. The virus is highly diverse and possesses several serotypes, genotypes and pathotypes. The virus is contained through commercially available inactivated and live vaccines (Weiss and Navas-Martin 2005; Fan et al. 2018). Moreover, the continuous emergence of novel strains with low cross-protection from vaccines sometime hampers the prevention and control strategies adopted on poultry farms (Zhang et al. 2020b). A few more CoVs from the genus Deltacoronavirus found infecting birds including Wigeon coronavirus HKU20, Bulbul coronavirus HKU11, Munia coronavirus HKU13, White-eye coronavirus HKU16, Night-heron coronavirus HKU19 and Common moorhen coronavirus HKU21 (Paim et al. 2019).

\section{ii. Porcine coronaviruses}

Several CoVs are found infecting pigs including Transmissible Gastroenteritis Virus (TGEV), Porcine respiratory coronavirus virus (PRCoV), Porcine Epidemic Diarrhea Virus (PEDV), Porcine hemagglutinating encephalomyelitis virus (PHEV), Swine acute diarrhoea syndrome coronavirus (SADS-CoV) and Porcine deltacoronavirus (PDCoV).

TGE is a highly contagious and economically significant disease of pigs reported all over the world (Weiss and Navas-Martin 2005). TGEV was first described in 1946 as a sporadic disease affecting pigs and characterized clinically by diarrhoea, vomition, rapid weight loss, and high mortality, predominantly in young pigs (Doyle and Hutchings 1946). The virus spread occurs through the faecal-oral route (ingestion). The clinical signs of TGE appear after a short incubation period of 18-72 hours. The virus selectively targets, multiplies and destroys the absorptive epithelial cells of the villi causing villous atrophy and impair absorption (malabsorption) (Wu et al. 2020). TGE cause severe diarrhoea with a watery, whitish or whitish-green stool. The upper respiratory tract and less often, the lungs also get affected with the disease (Enjuanes et al. 1995). Immunization of sows before farrowing is available with both live attenuated and killed vaccines.

Porcine respiratory coronavirus virus (PRCoV) is the attenuated variant of TGEV, originated due to a large 5' region deletion (621-681 nt) in the Spike (S) gene of the virus. The emergence of PRCoV is one of the examples of the evolution of CoVs with altered tropism and virulence (Saif 2004).

Another important porcine enteric disease PEDV, recognised in the early 1970s in Europe is growing and fattening pigs (Oldham 1972). Since its first report in 1982 in Asian countries, PEDV had a tremendous economic impact on the Asian pork industry (Lee 2015). The disease occurred in 2013 in the US, along with Canada and Mexico, causing deaths of more than 8 million piglets (Lee, 2015). Infection caused by oral and nasal route with an 
incubation period of 1-4 days. Though there is a similarity in disease symptoms with TGEV, it differs in the spread within the herd, which is comparatively slower and with low mortality (Lin et al. 2019).

Further, in PEDV older population affected more than younger ones (Tan et al. 2020). PEDV and TGEV use the same receptor for entry into the cell. The closest known relatives of PEDV are found in bats and humans (HCoV-NL63) (Saif 2004). Several vaccines are available for the control of disease in swine (Hsueh et al. 2020).

PHEV is known to affect the digestive and nervous system in pigs. It was first isolated in 1962 and classified under coronavirus in 1971 (Greig et al. 1962; Clarke and McFerran 1971). $\mathrm{PHEV}$ is one of the first $\mathrm{CoV}$ s identified with neurotropic properties in pigs (MoraDíaz et al. 2019). Due to low clinical prevalence, $\mathrm{PHEV}$ is the least explored swine CoV worldwide. PHEV infect pigs of all ages but the clinical manifestation, mortality and morbidity are high in piglets below four weeks of age. Serological survey data describes the worldwide subclinical presence of PHEV (Mora-Díaz et al. 2019).

SADS-CoV is a member of the genus Alphacoronavirus. It causes acute enteritis in the piglets. An early report on SADS-CoV had shown mortality of nearly 24,500 piglets in China. The SADS-CoV sequence analysis revealed high similarity (95-96\%) to horseshoe bat origin (Rhinolophus sp.) and was named as HKU2-CoV (Zhou et al. 2018). The disease outbreak projected the likelihood of host species leaping from bat $\mathrm{CoV}$ to pigs (Zhou et al. 2018).

PDCoV was identified in the porcine population for the first time in 2012 in Hong Kong (Woo et al. 2012a). Since then, PDCoV has spread to many countries, including China, Canada, Vietnam, Laos, USA, Thailand, and South Korea (Koonpaew et al. 2019). Clinical severity of PDCoV is mild than other porcine CoVs. The mortality rate during PDCoV outbreaks reaches up to $40 \%$ (Jung et al. 2016). As on date, limited information is available regarding the pathogenicity and virus-host interaction of PDCoV.

\section{iii. Lab animals}

The CoVs are also detected to infect several laboratory animals, including mice, ferret, guinea pig, rat, and rabbit. CoV-like mouse hepatitis virus (MHV), rat sialodacryoadenitis- $\mathrm{CoV}$, guinea pig-CoV, ferret-CoV, and rabbit-CoVs are some important $\mathrm{CoVs}$ found responsible for hepatitis, enteritis, and respiratory infections in the lab animals. MHV is the most important and explored laboratory animal CoV which vary widely in its tissue tropism. The highly contagious enterotropic MHV strains infect digestive tract of infant mice and cause up to $100 \%$ mortality (Compton et al. 2004). Whereas, polytropic 
MHV primarily affects the upper respiratory tract and secondarily several organs including lymph node, CNS, vascular endothelium, haemopoietic tissue and liver. Rat sialodacryoadenitis-CoV primarily target nasal respiratory epithelium which later spreads to salivary and lacrimal glands (Funk et al. 2009). High mortality rates observed in suckling rats. Ferrets are infected by enterotropic CoVs which cause epizootic catarrhal enteritis or green slime disease (Doria-Torra et al. 2016). Very little is known about the prevalence of CoVs infecting rabbit and guinea pig, which mainly cause enteric disease characterized by villous atrophy, malabsorption and diarrhoea (Lau et al. 2012).

\section{iv. Domestic and wild ruminants}

Among large animals, bovine coronaviruses (BoCoVs) have zoonotic potential as having been isolated from children. They may communicate a disease to many domestic and wild ruminants, in which calf diarrhoea in neonates, bloody diarrhoea in adult cattle and respiratory form of shipping fever in all age groups of animals are universal implications (Suzuki et al. 2020). The high mortality rate due to BoCoVs mostly attributed to its high capability of destroying villi of both large and small intestine leading to bloody diarrhoea (Torres-Medina et al. 1985). The presence of carrier animals and route of infection through faecal-oral is the primary cause of its spread (Carman and Hazlett 1992). Carrier animals mainly shed the virus in stress conditions like winter (Carman and Hazlett 1992). Besides affecting the bovine species, several Bovine-like CoVs have been reported from wild and domestic ruminants like Reindeer, Samber deer, White-tailed deer, Water deer, Wood bison, Waterbuck, Sable antelope, Himalayan tahr, Giraffe, Nyala, Sitatunga, Alpaca, Dromedary camel, Water buffalo, sheep, goat etc. (Amer 2018; Kim et al. 2018).

\section{v. Equine coronavirus}

Equine coronaviruses (ECoVs) were initially reported in foals of less than two weeks of age, and infect the host with or without overt clinical sign and mostly associated with mild enteritis (Dhama et al. 2014a). ECoVs belongs to the genus Betacoronavirus. ECoV was first reported in 1991 in foals from the USA and in an adult horse in 2011 in Japan (Guy et al. 2000; Pusterla et al. 2013). They are responsible for causing self-limiting enteritis in horse population (Sanz et al. 2019).

\section{vi. Companion animals}

Canine enteric coronavirus $(\mathrm{CCoV})$ of Alphacoronavirus and canine respiratory coronavirus $(\mathrm{CRCoV})$ of Betaacoronavirus genera affects the enteric and respiratory tract, respectively (Licitra et al. 2014). CCoVs are present worldwide and infect all ages of animals, though puppies are known to be affected more severely. CCoV was first reported in 
1971 in Germany from dogs with acute enteritis (Binn et al. 1974). CCoV also possesses two genotypes known as type I and II. Both the types can infect the same host at a time which favours the chances of recombination between virus strains (Escutenaire et al. 2007). CCoV shows more similarity with TGEV and probably TGEV originated from CCoV-II (Perlman and Netland 2009). As per tissue tropism, there are two types of CCoV known, an enterotropic which cause enteritis primarily and another pantropic which targets several organs including the liver, spleen, central nervous system (CNS), lung, and kidney (Buonavoglia et al. 2006). CCoV-I is not cultivable, but CCoV-II can quickly be grown in cell culture. CRCoV is more related to BoCoVs from Betacoronavirus genus and causes mild to a severe respiratory infection known as kennel cough (Erles et al. 2007; Szczepanski et al. 2019).

Feline infectious peritonitis virus (FIPV) and Feline enteric coronavirus (FECV) are two common CoVs affecting the feline population. Feline-CoVs affect the respiratory tract, CNS, abdominal cavity and gastrointestinal tract to produce enteritis and infectious peritonitis (Tekes and Thiel 2016). Feline infectious peritonitis (FIP) was first described in 1963 as a fatal and systemic progressive debilitating febrile disease of both domestic and wild feline (Holzworth 1963). FIPV originated from FECV due to mutation in the $S$ gene, which changes the tropism for macrophages (Rottier et al. 2005). All the feline CoVs belongs to the Alphacoronavirus genus, and two distinct serotypes have been identified. Serotype I is a comparatively common cause of infection than serotype II. Serotype II believed to have originated due to recombination with canine $\mathrm{CoV}$ (Herrewegh et al. 1998). The incubation period varies from as short as two weeks to as long as two months. The disease symptoms are seen typically in very young and old animals concerning suppressed immunity. The disease has two distinct forms, one is wet (effusive), and another is dry (non-effusive) (Kipar et al. 2005). Host immune response is mainly responsible for the particular disease form. Antigenantibody complexes are considered responsible for the lesions in the wet way (Jaimes et al. 2020). The CNS dysfunction is most commonly seen during the dry form. Though both the types are fatal, still wet from proceeds more rapidly.

\section{vii. Marine coronavirus}

In addition to terrestrial animals, a novel coronavirus named SW1-CoV was recognized using state-of-art panviral microarray technology from the liver tissue specimens of the captive beluga whale (Delphinapterus leucas) (Mihindukulasuriya et al. 2008). The name beluga derived from the Russian word "bielo" meaning white. This highly vocal beluga whale is known for its white colour and globular head and counted as a social animal. The 
beluga whale belongs to the Monodontidae family and lives in the cold waters of the Arctic and some subarctic regions. Marine CoVs also have been reported from novel bottlenose dolphin reveals a distinct species in Gammacoronavirus (Woo et al. 2014).

\section{viii. Bat coronaviruses}

Since the identification of many CoVs in bats, these are now considered as ideal reservoirs for CoVs. The bats harbour CoVs persistently for an extended period as an asymptomatic carrier and while flying in search of food might shed the virus in more extensive areas including some animal-human hosts which come in direct or indirect contact (Fan et al. 2019). Notably, in China, bats are used as food as well as used to prepare Traditional Chinese Medicine (TCM). Bats pose a higher risk of transmitting a new zoonotic infection (Wassenaar and Zou 2020).

\section{Origin of SARS-CoV-2 and animal linkages (zoonosis)}

The first case of pneumonia of unknown origin appeared in the South China Wet Seafood wholesale market in Wuhan, Hubei Province, China, was further investigated and found to be due to coronavirus. The live animal market with restaurants in this place is known for servings of several types of wild and live animals including bats, snakes, and marmots (Hu et al. 2015; Hui et al. 2020; Lu et al. 2020). A few researcher groups also suggested the role of traditional cooking practices in China accountable for the current $\mathrm{CoV}$ infection in humans. Though in China live-slaughtered animals are considered more nutritious, several pathogens including SARS-CoV, Nipah virus, Hepatitis A virus, Hepatitis E virus, Norovirus, Rotavirus, Highly Pathogenic Avian Influenza virus also pass on through this way of food servings (FAO/WHO 2008). Looking as the scare situation, the government of China banned the sale of wildlife and trading of bats, Wuhan animal food market was closed to avoid zoonotic transmission of COVID-19 and evolution of any new viral variant (Benvenuto et al. 2020). Later the virus was named 2019-nCoV/SARS-CoV-2. The original link of $\mathrm{CoV}$ was suspected to be from animal to human, and subsequently, virus maintained human-to-human transmission (Hui et al. 2020; Ji et al. 2020; Nishiura et al. 2020).

\section{Bat-like SARS-CoV linkage}

The perusal of literature revealed the prospective role of bat origin SARS-CoVs in infecting humans. Since the establishment of bats involvement in the transmission of SARSCoV in 2002/2003 outbreaks occurred in China, the scientist's conjectured bats association in the current epidemic of SARS-CoV-2/COVID-2019 as well (Fan et al. 2019; Wong et al. 2019; Zhou et al. 2020a). The resemblance of bat CoVs with current SARS-CoV-2 at the genomic level has been evaluated by several research groups world over. The SARS-CoV-2 
has shown the similarity of 88-89\% with two bat origin SARS-CoVs (bat-SL-CoVZC45 and bat-SL-CoVZXC21 or also named as ZC45 and ZXC21). The similarity of SARS-CoV-2 at genomic level remains lower (82\%) with human SARS-CoV Tor2 and human SARS-CoV BJ01 2003 (Drexler et al. 2014; Hu et al. 2017; Hu et al. 2018; Chan et al. 2020; Malik et al. 2020). The genomic level phyloanalysis reveal the greater closeness of SARS-CoV-2 with bat origin SARS-CoVs (Mohd et al. 2016; Ramadan and Shaib 2019; Malik et al. 2020; Ren et al. 2020). Now, surveillance strategies and preventive guidelines should be drafted to have an analysis of bat origin Betacoronavirus especially in the Rhinolophus bat family as in the past SARS, MERS, and now COVID-19 epidemic has become havoc. From epidemic, it is turning to pandemic (Daszak et al. 2020).

Bat coronavirus (BatCoV RaTG13) — which was previously detected in Rhinolophus affinis from Yunnan province-showed high sequence identity to SARS-CoV-2. Simplot analysis reveals the highest similarity of SARS-CoV-2 throughout the genome to RaTG13, with an overall genome sequence identity of $96.2 \%$. The receptor-binding spike protein (S) was highly divergent from other previously described SARS-CoVs, except for a $93.1 \%$ nucleotide identity to RaTG13. The $S$ genes of SARS-CoV-2 and RaTG13 are longer than other SARSr-CoVs. The close phylogenetic relationship to RaTG13 provides evidence that SARS-CoV-2 may have originated in bats (Zhou et al. 2020b).

\section{Malayan pangolin-CoV linkage}

In addition to bats, $\mathrm{CoV}$ has been isolated from Malayan pangolin (Manis javanica) also known as Sunda pangolin or Javan pangolin, a mammalian species under the order Pholidota and the critically endangered species under the Red List of International Union for the Conservation of Nature (IUCN) (Lam et al. 2020). Notably, the RBD region in the $S$ protein of SARS-CoV-2/2019-nCoV was found closely related to that of Malayan pangolinCoV (Wong et al. 2020). This finding suggests the pangolin role as an intermediate host of ongoing CoV-2 epidemic (Xiao et al. 2020). Further studies might be needed to approve this assumption fully. It is found throughout Southeast Asia, including Brunei, Cambodia, Java, Sumatra, Borneo, the Lesser Sunda Islands, Laos, Malaysia, Singapore, Thailand, Myanmar and Vietnam. It prefers forested habitats and plantations. The chances of spread of CoV-2 from pangolins are emphasized as the demand for pangolin's meat is high as well as the overlapping keratinized outer skin scales are having a value in TMC (Liu et al. 2020b). These mammals, due to global demand, are most poached and trafficked mammals. 


\section{First-case of SARS-CoV-2 Human to animal transmission (Reverse Zoonoses)}

Currently, the knowledge about the origin of this virus, its receptor binding motif in the host and its natural host are not known. Speculations suggest their origin to Bat-SARSLike coronaviruses is still a point of the question. Few preliminary studies indicate that the recent SARS-CoV-2 is genetically similar to pangolin CoVs and a group of bat CoVs yet phylogenetic analysis failed to prove their ancestor directly from pangolin CoVs. A recent report also confirmed the transmission of SARS-CoV-2 to pet dog where the dog was found with mild respiratory illness symptoms of COVID-19 disease. Dogs are known to harbour Canine Respiratory coronaviruses $(\mathrm{CRCoVs})$ which are responsible for severe respiratory problem dogs, and they fall in a different subgenus called Embecovirus (Szczepanski et al. 2019). CRCoVs are related to bovine coronavirus (BCoV) and human coronavirus-OC43 which are Betacoronaviruses (Szczepanski et al. 2019). They are further distinct to canine enteric coronavirus (CECoV), which are Alphacoronaviruses, and known for enteric infections in dogs. Phylogenetically, a bat origin isolates Bat-CoV-RaTG13 (Accession no. MN996532) was found closer to SARS-CoV-2 which may play as an intermediate host involved in the origin of this current outbreak strain ( $\mathbf{L v}$ et al. 2020).

\section{Clinical picture and disease pathology}

Because of the severity of COVID-19 infection, four types of infections are seen, including mild, moderate, severe, and critical. The COVID-19 infected patient exhibit clinical symptoms such as fever, dry cough, myalgia, fatigue, and diarrhoea (Chen 2020; Huang et al. 2020). A few of the sufferers also exhibit dyspnoea and lymphopenia. The expected incubation period of COVID-19 varies from 2-24 days. In complicated cases, acute cardiac injury and secondary infections also occur (Huang et al. 2020). The chest computed tomography (CT) show abnormal bilateral ground-glass opacity in the asymptomatic patients (Huang et al. 2020), while in severely ill patients bilateral multiple lobular and subsegmental areas of consolidation are seen (Huang et al. 2020). The virological and clinical picture of the SARS-CoV-2 and COVID-19 is still not clear and under investigation. The COVID-19 pathology prominently is similar to SARS and MERS-CoVs infection (Tian et al. 2020; Xu et al. 2020b). The SARS-CoV-2 majority injury the lower respiratory tract and virus hits the epithelial cells leading to alveolar damage. It further affects other organs, including intestinal mucosa, kidney, brain, among others (Luo et al. 2020; Xu et al. 2020b). In later stages of COVID-19 infection, death noticed as of substantial alveolar damage and respiratory failure (Tian et al. 2020). 


\section{Virus Diagnosis}

The COVID-19 diagnosis faces difficulty in the absence of apparent clinical symptoms, unusually at early stages of the infection where the laboratory findings and chest radiographic images fail to yield any conclusive idea of COVID-19 infection. However, the new sequence information from virus genome of SARS-CoV-2 aided in developing rapid point-of-care molecular tools such as real-time quantitative reverse transcription-polymerase chain reaction (RT-PCR) diagnostic tests specific for SARS-CoV-2 (2019-nCoV) and differentiates from other SARS-CoV and MERS-CoVs. Now the frequent laboratory confirmation of COVID-19 cases is based on either nucleic acid-based virus genome sequencing, RT-PCR, real-time PCR, real-time RT-PCR (rRT-qPCR), POCT/bedside testing, serological methods including Enzyme-linked immunoassay, and computed tomography technique (CT) imaging and X-Ray (Corman et al. 2012; Dhama et al. 2020a; Huang et al. 2020; Xu et al. 2020a; Zhang et al. 2020a). A reverse transcriptional loop-mediated isothermal amplification (RT-LAMP) diagnostic tool has also been designed for rapid and colourimetric detection of SARS-CoV-2 (Yu et al. 2020). An interactive web-based dashboard to track COVID-19 in real-time has also been developed (Dong et al. 2020). The cumbersomeness and costly applications of genome-based sequencing methods have shown their limited use in identification of the pathogen.

On the other hand, nucleic acid amplification assays such as real-time PCR are targeting the spike (S), and nucleocapsid (N) genes are widely available. Several manufacturers have commercialized in the kit format for early and accurate detection of the SARS-CoV-2. However, the false positivity and cross-contamination amplifications come as a hurdle in these assays result confirmation. Recently, a fluorescence-based quantitative PCR assay was developed based on N and ORF1ab regions on the SARS-CoV-2 genome (Wang et al. 2020). Among serological tests, ELISA is preferred because of higher sensitivity and detection limit for COVID-19 virus and takes a short time in providing results at low costs. Clinical samples suitable for COVID-19 diagnosis comprise of sputum, endotracheal aspirate, bronchoalveolar lavage, blood, serum, nasopharyngeal swabs and oropharyngeal swabs. Countries lacking diagnostic facilities need to follow up with proper laboratory shipping guidelines for transferring to WHO reference laboratories.

\section{SARS-CoV-2/COVID-2019 vaccines and therapeutics}

Since the reporting of the first case, several re-purposed medicines, including some traditional Chinese herbal medicines, have been evaluated for their anti-COVID-19 activity (Dhama et al. 2020a). A few of the genetically targeted antiviral therapies, drugs, and 
vaccines, including some engineered monoclonal antibodies would prove useful in combating the ongoing global threat (Liu et al. 2020c; Moderna 2020; NIAID 2020; Shanmugaraj et al. 2020). Recent threats of epidemics and pandemics posed by Ebola, Zika, Nipah, and earlier ones of swine flu, avian flu, SARS-CoV-2, MERS-CoV have paved pace for developing an effective and advanced vaccine and therapeutics and drugs, and hopefully, soon we will have suitable vaccines and drugs to counter the present COVID-19 pandemic (Dhama et al. 2012; Dhama 2013; Munjal et al. 2017; Dhama et al. 2018; Singh et al. 2019; Dhama et al. 2020a; Di Pierro et al. 2020; DST and Health Commission China 2020; Li et al. 2020a; Malik et al. 2020). Few of the initiatives to develop COVID vaccines include chimpanzee adenovirus vectored vaccine (NIAID 2020). The vaccine being developed by Moderna Therapeutics is anticipated by the end of April 2020 (Moderna 2020), and Kaiser Permanente Washington, Health Research Institute, intends to build vaccine in coming time (LiveScience 2020).

Gilead Sciences (NASDAQ-GILD) is testing remdesivir against SARS CoV-2; Moderna (NASDAQ: MRNA) manufactured mRNA-based vaccine (mRNA-1273), which is under clinical trials. Inovio Pharmaceuticals (NASDAQ-INO) designing INO-4800 as a vaccine candidate. US President Donald Trump boosted significant pharmaceutical companies such as Johnson \& Johnson (NYSE: JNJ), Sanofi (NASDAQ: SNY) and Pfizer (NYSE: PFE) to develop potent vaccines and effective drugs to counter COVID-19 (Fool 2020).

\section{Prevention and control}

The past information based on tackling the SARS- and MERS- CoVs epidemics in 2002 and 2012 have been used instantly to combat the spread of the current pandemic due to the SARS-CoV-2/COVID-19. Additionally, the progress made in the field of disease diagnosis and vaccines development proved helpful in developing rapid and accurate diagnostics as well as effective vaccines (Dhama et al. 2020a; Dhama et al. 2020b; Rodriguez-Morales et al. 2020a). The disease diagnostic kits are available in the market which differentiates between different types of the CoVs and the vaccines developed to counter COVID-19 infection is in the final stages of clinical trials. In networking mode, several countries have entered in collaboration making the vaccine on priority to safeguard the public. Like the virus, SARS-CoV-2 has spread across more than 125 countries, efforts have been initiated to control its further spread, and presently high efforts are being made and tackle the pandemic situation (Gao 2020b; Guo et al. 2020; Wilder-Smith et al. 2020) Therefore, worldwide countries have emphasised the strict vigilance of entry of travellers at tourism sites as well as their people using correction diagnostics, instant isolation and 
quarantine of suspected patients, equipped with best medical facilities for handling any untoward situation (Hellewell et al. 2020; Khan et al. 2020; Malik et al. 2020; RodriguezMorales et al. 2020c; Wilson and Chen 2020). Apart from large scale awareness programmes for the public have been initiated to educate the public on the COVID-19 associated disease health risks. Seeing the high socio-economic impacts and implications related to SARS-CoV-2 / COVID-19, various kind of advisories and preventive measures have been advised to avoid infection from this virus such as closing schools and offices for a while, preventing international tours and travels to the affected countries/regions, cancellation of visas, recommendations to public to stay at home in affected areas, along with designing and implementing appropriate strategies during pandemic to be implemented and challenges ahead (Ayittey et al. 2020; Biscayart et al. 2020; CDC 2020; Cohen and Kupferschmidt 2020; Lai et al. 2020; WHO 2020).

Furthermore, there is a need to strengthen the medical infrastructure and human resources development in the medical arena. Strict compliance of the provided guidelines of Centres for Disease Control and Prevention (CDC) is a must. As the COVID-19 cases may lead to nosocomial infections in health-care workers, they must adopt all good hygiene and health practices while dealing with COVID-19 patient. The spread of the virus through contact must be blocked. The environmental surface cleaning with $70 \%$ ethanol or $0.5 \%$ sodium hypochlorite solutions are advised besides, personnel hygiene including hand hygiene and restricting touch of nose and face (Dhama et al. 2020b; Rodriguez-Morales et al. 2020a). With zoonotic links associated with the virus, effective implementation of One health approach may also play a crucial role in controlling the further spread of this pandemic virus (Dhama et al. 2013; Bonilla-Aldana et al. 2020; OIE 2020; Rodriguez-Morales et al. 2020b).

\section{Conclusion and prospects}

Even the case fatality rate in the current COVID-19 epidemic is much lower than the previous human coronaviruses (SARS-CoV and MERS-CoV), on March 11, 2020, the SARS-CoV-2 affected 118326 humans and claimed 4292 deaths world over affecting 114 countries. Nevertheless, the latest reports from China shows effective containment of the spread of SARS-CoV-2 in the epicentre, Wuhan area, the COVID-19 cases are on surge globally. Majorly the spread has linked to travellers flying from affected areas. In India, the first case of COVID-19 was reported on January 30, 2020, with the entry of three students from Wuhan city and now within 42 days, the cases have surged to 73 (56 Indian nationals and 17 Foreign nationals) affecting 12 states/regions as on $12^{\text {th }}$ March 2020 . The restriction 
has been enforced on all international air terminals and seaports with compliance of strict vigilance of persons. The diagnostics are available not only useful in detecting SARS-CoV-2 but also differentiates it from other human-CoVs. Promisingly, good signs have noticed on developments of anti-SARS-CoV-2 vaccine which possess the potential to combat emerging global threat effectively. The availability of SARS-CoV-2 genome sequences from different parts of global in the public domain has helped researchers to dig out important information on virus pathobiology and designing of virus-specific antivirals. However, until we get a practical approach to win over the COVID-19 infection, there is a need to rely on the available re-purposed drugs which are also found useful. The computational biology approaches might also show some right way to design virus-specific therapeutic shortly. The transmission routes play an essential role in the maintenance of the virus in humans. Although a few of the direct transmission routes have been suggested, including aerosol/contact, vertical transmission (mother to foetus) of SARS-CoV-2 needs further investigation. The observation of a mild-infection in the pet dog of a COVID-19 infected patient in Hong Kong has shown Human-to-animal transmission (zooanthroponotic) route but need further research to establish the finding. It is anticipated that near future will see an apparent triumph over the COVID-19 infection under the collective effort of virologists, clinicians, pharmacology and epidemiology researchers working globally in network mode.

\section{Acknowledgements}

All the authors acknowledge and thank their respective Institutes and Universities.

\section{Author contributions}

All the authors substantially contributed to the conception, design, analysis and interpretation of data, checking and approving the final version of the manuscript, and agree to be accountable for its contents.

\section{Funding}

This compilation is a review article written, analyzed and designed by its authors and required no substantial funding to be stated.

\section{Disclosure statement}

All authors declare that there exist no commercial or financial relationships that could, in any way, lead to a potential conflict of interest. 


\section{References}

1 Amer H M. 2018. Bovine-like coronaviruses in domestic and wild ruminants. Animal Health Research Reviews 19(2): 113-24

2 Ayittey F K, Ayittey M K, Chiwero N B, Kamasah J S and Dzuvor C. 2020. Economic impacts of Wuhan 2019-nCoV on China and the world. Journal of Medical Virology 2020: 1-3

3 Benvenuto D, Giovannetti M, Ciccozzi A, Spoto S, Angeletti S and Ciccozzi M. 2020. The 2019-new coronavirus epidemic: evidence for virus evolution. Journal of Medical Virology 92: 455-59

4 Binn L, Lazar E, Keenan K, Huxsoll D, Marchwicki R and Strano A. 1974. Recovery and characterization of a coronavirus from military dogs with diarrhea. In Proceedings,... annual meeting of the United States Animal Health Association.

5 Biscayart C, Angeleri P, Lloveras S, Chaves T, Schlagenhauf P and RodríguezMorales A J. 2020. The next big threat to global health? 2019 novel coronavirus (2019-nCoV): What advice can we give to travellers?-Interim recommendations January 2020, from the Latin-American society for Travel Medicine (SLAMVI). Travel Medicine and Infectious Disease 33: 101567

6 Bonilla-Aldana D, Dhama K and Rodriguez-Morales A. 2020. Editorial : Revisiting the One Health Approach in the Context of COVID-19: A Look into the Ecology of this Emerging Disease. Advances in Animal and Veterinary Sciences 8: 13.10.17582/journal.aavs/2020/8.3.234.237

7 Buonavoglia C, Decaro N, Martella V, Elia G, Campolo M, Desario C, Castagnaro M and Tempesta M. 2006. Canine coronavirus highly pathogenic for dogs. Emerging Infectious Diseases 12(3): 492

8 Carman P S and Hazlett M J. 1992. Bovine coronavirus infection in Ontario 19901991. The Canadian Veterinary Journal 33(12): 812

9 Cavanagh D. 2007. Coronavirus avian infectious bronchitis virus. Veterinary Research 38(2): 281-97

10 CDC. 2020. Coronavirus Disease 2019 (COVID-19): Steps to Prevent Illness. Centers for Disease Control and Prevention. https://www.cdc.gov/coronavirus/2019ncov/about/prevention-treatment.html. .

11 Chan J F-W, Kok K-H, Zhu Z, Chu H, To K K-W, Yuan S and Yuen K-Y. 2020. Genomic characterization of the 2019 novel human-pathogenic coronavirus isolated 
from a patient with atypical pneumonia after visiting Wuhan. Emerging Microbes \& Infections 9(1): 221-36

12 Chen J. 2020. Pathogenicity and transmissibility of 2019-nCoV—a quick overview and comparison with other emerging viruses. Microbes and infection 22(2): 69-71

13 Clarke J and McFerran J. 1971. An electron microscopic study of haemagglutinating encephalomyelitis virus of pigs. Journal of General Virology 13(2): 339-44

14 Cohen J and Kupferschmidt K. 2020. Strategies shift as coronavirus pandemic looms. Science 367(6481): 962.10.1126/science.367.6481.962

15 Compton S R, Ball-Goodrich L J, Johnson L K, Johnson E A, Paturzo F X and Macy J D. 2004. Pathogenesis of enterotropic mouse hepatitis virus in immunocompetent and immunodeficient mice. Comparative Medicine 54(6): 681-89

16 Corman V, Eckerle I, Bleicker T, Zaki A, Landt O, Eschbach-Bludau M, van Boheemen S, Gopal R, Ballhause M and Bestebroer T. 2012. Detection of a novel human coronavirus by real-time reverse-transcription polymerase chain reaction. Eurosurveillance 17(39)

17 Cui J, Li F and Shi Z-L. 2019. Origin and evolution of pathogenic coronaviruses. Nature reviews Microbiology 17(3): 181-92

18 Daszak P, Olival K J and Li H. 2020. A strategy to prevent future pandemics similar to the 2019-nCoV outbreak. Biosafety and Health

19 de Groot R J, Baker S, Baric R, Enjuanes L, Gorbalenya A, Holmes K, Perlman S, Poon L, Rottier P and Talbot P. 2012. Family coronaviridae. Virus taxonomy: 806-28

20 Dhama K. 2013. Avian/Bird Flu Virus: Poultry Pathogen Having. J. Med. Sci 13(5): $301-15$

21 Dhama K, Chakraborty S, Kapoor S, Tiwari R, Kumar A, Deb R, Rajagunalan S, Singh R, Vora K and Natesan S. 2013. One world, one health-veterinary perspectives. Adv. Anim. Vet. Sci 1(1): 5-13

22 Dhama K, Karthik K, Khandia R, Chakraborty S, Munjal A, Latheef S K, Kumar D, Ramakrishnan M A, Malik Y S and Singh R. 2018. Advances in designing and developing vaccines, drugs, and therapies to counter Ebola virus. Frontiers in Immunology 9: 1803

23 Dhama K, Khan S, Tiwari R, Dadar M, Malik Y, Singh K and Chaicumpa W. 2020a. COVID-19, an emerging coronavirus infection: Advances and prospects in designing and developing vaccines, immunotherapeutics and therapeutics- A Mini-Review. Human Vaccines and Immunotherapeutics 16.10.1080/21645515.2020.1735227 
24 Dhama K, Pawaiya R, Chakraborty S, Tiwari R, Saminathan M and Verma A K. 2014a. Coronavirus infection in equines: A review. Asian Journal of Animal and Veterinary Advances 9(3): 164-76

25 Dhama K, Saminathan M, Karthik K, Tiwari R, Shabbir M Z, Kumar N, Malik Y S and Singh R K. 2015. Avian rotavirus enteritis-an updated review. Veterinary Quarterly 35(3): 142-58

26 Dhama K, Sharun K, Tiwari R, Sircar S, Bhat S, Malik Y S, Singh K P, Chaicumpa W, Bonilla-Aldana D K and Rodriguez-Morales A J. 2020b. Coronavirus Disease 2019 - COVID-19. Preprints 2020(202003000 DOI: 10.20944/preprints202003.0001.v1)

27 Dhama K, Singh S D, Rajamani B, Desingu P, Sandip C, Ruchi T and Kumar M. 2014b. Emergence of avian infectious bronchitis virus and its variants need better diagnosis, prevention and control strategies: a global perspective. Pakistan Journal of Biological Sciences 17(6): 751-67

28 Dhama K, Verma A K, Rajagunalan S, Deb R, Karthik K, Kapoor S, Tiwari R, Panwar P K and Chakraborty S. 2012. Swine flu is back again: a review. Pakistan journal of biological sciences: PJBS 15(21): 1001-09

29 Di Pierro F, Bertuccioli A and Cavecchia I. 2020. Possible therapeutic role of a highly standardized mixture of active compounds derived from cultured Lentinula edodes mycelia (AHCC) in patients infected with 2019 novel coronavirus. Minerva Gastroenterologica e Dietologica: 10.23736/S1121-421X.20.02697-5.DOI: 10.23736/S1121-421X.20.02697-5

30 Dong E, Du H and Gardner L. 2020. An interactive web-based dashboard to track COVID-19 in real time. The Lancet Infectious Diseases.DOI: 10.1016/S14733099(20)30120-1

31 Doria-Torra G, Vidaña B, Ramis A, Amarilla S and Martínez J. 2016. Coronavirus infection in ferrets: antigen distribution and inflammatory response. Veterinary Pathology 53(6): 1180-86

32 Doyle L and Hutchings L. 1946. A transmissible gastroenteritis in pigs. Journal of the American Veterinary Medical Association 108: 257-59

33 Drexler J F, Corman V M and Drosten C. 2014. Ecology, evolution and classification of bat coronaviruses in the aftermath of SARS. Antiviral Research 101: 45-56

34 DST and Health Commission China. 2020. Expert consensus on chloroquine phosphate for the treatment of novel coronavirus pneumonia. Chinese Journal of 
Tuberculosis and Respiratory diseases 43(3): 185-88.10.3760/cma.j.issn.10010939.2020.03.009

35 Du Toit A. 2020. Outbreak of a novel coronavirus. Nature reviews Microbiology 18(3): $123-23$

36 Enjuanes L, Smerdou C, Castilla J, Antón I M, Torres J M, Sola I, Golvano J, Sánchez J M and Pintado B. 1995. Development of protection against coronavirus induced diseases. In Corona-and Related Viruses, pp 197-211. Springer.

37 Erles K, Shiu K-B and Brownlie J. 2007. Isolation and sequence analysis of canine respiratory coronavirus. Virus Research 124(1-2): 78-87

38 Escutenaire S, Isaksson M, Renström L, Klingeborn B, Buonavoglia C, Berg M, Belak S and Thoren P. 2007. Characterization of divergent and atypical canine coronaviruses from Sweden. Archives of Virology 152(8): 1507-14

39 Fan W-S, Li H-M, He Y-N, Tang N, Zhang L-H, Wang H-Y, Zhong L, Chen J-C, Wei T-C and Huang T. 2018. Immune protection conferred by three commonly used commercial live attenuated vaccines against the prevalent local strains of avian infectious bronchitis virus in southern China. Journal of Veterinary Medical Science 80(9): $1438-44$

40 Fan Y, Zhao K, Shi Z-L and Zhou P. 2019. Bat Coronaviruses in China. Viruses 11(3): 210

41 FAO/WHO. 2008. Microbiological hazards in fresh leafy vegetables and herbs: Meeting Report. Microbiological Risk Assessment Series 14: 151

42 Fool. 2020. Trump to Meet With Pharmaceutical Companies About Coronavirus. Fool.com. https://www.fool.com/investing/2020/03/02/trump-to-meet-withpharmaceutical-companies-about.aspx.

43 Funk C J, Manzer R, Miura T A, Groshong S D, Ito Y, Travanty E A, Leete J, Holmes K V and Mason R J. 2009. Rat respiratory coronavirus infection: replication in airway and alveolar epithelial cells and the innate immune response. The Journal of General Virology 90(Pt 12): 2956-64

44 Gao Z. 2020a. Efficient management of novel coronavirus pneumonia by efficient prevention and control in scientific manner. Chinese Journal of Tuberculosis and Respiratory Diseases 43: E001

45 Gao Z C. 2020b. Efficient management of novel coronavirus pneumonia by efficient prevention and control in scientific manner. Zhonghua jie he he hu xi za zhi= Zhonghua jiehe he huxi zazhi = Chinese journal of tuberculosis and respiratory diseases 43(3): 163-66.10.3760/cma.issn.1001-0939.2020.03.002 
46 Gorbalenya A E. 2020. Severe acute respiratory syndrome-related coronavirus-The species and its viruses, a statement of the Coronavirus Study Group. BioRxiv 2020.02.07.937862: 1-15.DOI: $10.1101 / 2020.02 .07 .937862$

47 Gralinski L E and Menachery V D. 2020. Return of the Coronavirus: 2019-nCoV. Viruses 12(2): 135

48 Greig A, Mitchell D, Corner A, Bannister G, Meads E and Julian R. 1962. A hemagglutinating virus producing encephalomyelitis in baby pigs. Canadian Journal of Comparative Medicine and Veterinary Science 26(3): 49

49 Guo Y, Huang Y M, Huang J, Jin Y Z, Jiang W, Liu P L, Liu F J, Ma J X, Ma J Y, Wang Y, et al. 2020. COVID-19 Pandemic: global epidemiological trends and China's subsequent preparedness and responses. Zhonghua liu xing bing xиe za zhi= Zhonghua liuxingbingxue zazhi 41(5): 643-48.10.3760/cma.j.cn112338-2020030100222

50 Guy J S, Breslin J J, Breuhaus B, Vivrette S and Smith L G. 2000. Characterization of a coronavirus isolated from a diarrheic foal. Journal of Clinical Microbiology 38(12): 4523-26

51 Habibzadeh P and Stoneman E K. 2020. The Novel Coronavirus: A Bird's Eye View. The international journal of occupational and environmental medicine 11(2): 65

52 Hellewell J, Abbott S, Gimma A, Bosse N I, Jarvis C I, Russell T W, Munday J D, Kucharski A J, Edmunds W J, Sun F, et al. 2020. Feasibility of controlling COVID-19 outbreaks by isolation of cases and contacts. The Lancet Global Health.https://doi.org/10.1016/S2214-109X(20)30074-7

53 Herrewegh A A, Smeenk I, Horzinek M C, Rottier P J and de Groot R J. 1998. Feline coronavirus type II strains 79-1683 and 79-1146 originate from a double recombination between feline coronavirus type I and canine coronavirus. Journal of Virology 72(5): 4508-14

54 Holzworth J. 1963. Some important disorders of cats. The Cornell Veterinarian 53: $157-60$

55 Hsueh F-C, Chang Y-C, Kao C-F, Hsu C-W and Chang H-W. 2020. Intramuscular Immunization with Chemokine-Adjuvanted Inactive Porcine Epidemic Diarrhea Virus Induces Substantial Protection in Pigs. Vaccines 8(1): 102

$56 \mathrm{Hu}$ B, Ge X, Wang L-F and Shi Z. 2015. Bat origin of human coronaviruses. Virology Journal 12(1): 221

57 Hu B, Zeng L-P, Yang X-L, Ge X-Y, Zhang W, Li B, Xie J-Z, Shen X-R, Zhang Y-Z and Wang N. 2017. Discovery of a rich gene pool of bat SARS-related coronaviruses 
provides new insights into the origin of SARS coronavirus. PLoS Pathogens 13(11): e1006698

58 Hu D, Zhu C, Ai L, He T, Wang Y, Ye F, Yang L, Ding C, Zhu X and Lv R. 2018. Genomic characterization and infectivity of a novel SARS-like coronavirus in Chinese bats. Emerging microbes \& infections 7(1): 1-10

59 Huang C, Wang Y, Li X, Ren L, Zhao J, Hu Y, Zhang L, Fan G, Xu J and Gu X. 2020. Clinical features of patients infected with 2019 novel coronavirus in Wuhan, China. The Lancet 395(10223): 497-506

60 Hui D S, I Azhar E, Madani T A, Ntoumi F, Kock R, Dar O, Ippolito G, Mchugh T D, Memish Z A and Drosten C. 2020. The continuing 2019-nCoV epidemic threat of novel coronaviruses to global health-The latest 2019 novel coronavirus outbreak in Wuhan, China. International Journal of Infectious Diseases 91: 264-66

61 Jaimes J A, Millet J K, Stout A E, André N M and Whittaker G R. 2020. A Tale of Two Viruses: The Distinct Spike Glycoproteins of Feline Coronaviruses. Viruses 12(1): 83

62 Ji W, Wang W, Zhao X, Zai J and Li X. 2020. Cross-species transmission of the newly identified coronavirus 2019-nCoV. Journal of Medical Virology 92(4): 433-40

63 Jung K, Hu H and Saif L J. 2016. Porcine deltacoronavirus infection: etiology, cell culture for virus isolation and propagation, molecular epidemiology and pathogenesis. Virus Research 226: 50-59

64 Khan S, Siddique R, Ali A, Xue M and Nabi G. 2020. Novel coronavirus, poor quarantine, and the risk of pandemic. Journal of Hospital Infection.DOI: 10.1016/j.jhin.2020.02.002

65 Kim J H, Jang J H, Yoon S W, Noh J Y, Ahn M J, Kim Y, Jeong D G and Kim H K. 2018. Detection of bovine coronavirus in nasal swab of non-captive wild water deer, Korea. Transboundary and Emerging Diseases 65(3): 627-31

66 Kipar A, May H, Menger S, Weber M, Leukert W and Reinacher M. 2005. Morphologic features and development of granulomatous vasculitis in feline infectious peritonitis. Veterinary Pathology 42(3): 321-30

67 Koonpaew S, Teeravechyan S, Frantz P N, Chailangkarn T and Jongkaewwattana A. 2019. PEDV and PDCoV pathogenesis: the interplay between host innate immune responses and porcine enteric coronaviruses. Frontiers in Veterinary Science 6: 34

68 Lai C-C, Shih T-P, Ko W-C, Tang H-J and Hsueh P-R. 2020. Severe acute respiratory syndrome coronavirus 2 (SARS-CoV-2) and coronavirus disease-2019 (COVID-19): 
The epidemic and the challenges. International Journal of Antimicrobial Agents 55(3): 105924.https://doi.org/10.1016/j.ijantimicag.2020.105924

69 Lam T T-Y, Shum M H-H, Zhu H-C, Tong Y-G, Ni X-B, Liao Y-S, Wei W, Cheung W Y-M, Li W-J and Li L-F. 2020. Identification of 2019-nCoV related coronaviruses in Malayan pangolins in southern China. bioRxiv 2020.02.13.945485: 1-20.DOI: 10.1101/2020.02.13.945485

70 Lau S K, Woo P C, Yip C C, Fan R Y, Huang Y, Wang M, Guo R, Lam C S, Tsang A K and Lai K K. 2012. Isolation and characterization of a novel Betacoronavirus subgroup A coronavirus, rabbit coronavirus HKU14, from domestic rabbits. Journal of Virology 86(10): 5481-96

71 Lee C. 2015. Porcine epidemic diarrhea virus: an emerging and re-emerging epizootic swine virus. Virology Journal 12(1): 193

72 Li H, Wang Y M, Xu J Y and Cao B. 2020a. Potential antiviral therapeutics for 2019 Novel Coronavirus. Chinese Journal of Tuberculosis and Respiratory Diseases 43(3): 170-72.10.3760/cma.j.issn.1001-0939.2020.03.004

73 Li Q, Guan X, Wu P, Wang X, Zhou L, Tong Y, Ren R, Leung K S, Lau E H and Wong J Y. 2020b. Early transmission dynamics in Wuhan, China, of novel coronavirus-infected pneumonia. New England Journal of Medicine.10.1056/NEJMoa2001316

74 Licitra B N, Duhamel G E and Whittaker G R. 2014. Canine enteric coronaviruses: emerging viral pathogens with distinct recombinant spike proteins. Viruses $6(8)$ : 3363-76

75 Lin C-M, Ghimire S, Hou Y, Boley P, Langel S N, Vlasova A N, Saif L J and Wang Q. 2019. Pathogenicity and immunogenicity of attenuated porcine epidemic diarrhea virus PC22A strain in conventional weaned pigs. BMC Veterinary Research 15(1): 111

76 Liu J, Zheng X, Tong Q, Li W, Wang B, Sutter K, Trilling M, Lu M, Dittmer U and Yang D. 2020a. Overlapping and discrete aspects of the pathology and pathogenesis of the emerging human pathogenic coronaviruses SARS-CoV, MERS-CoV, and 2019-nCoV. Journal of Medical Virology

77 Liu P, Jiang J-Z, Hua Y, Wang X, Hou F, Wan X-F, Chen J, Zou J and Chen J. 2020b. Are pangolins the intermediate host of the 2019 novel coronavirus (2019-nCoV)? bioRxiv 2020.02.18.954628: 1-30.DOI: 10.1101/2020.02.18.95462 
78 Liu W, Zhu H L and Duan Y. 2020c. Effective Chemicals against Novel Coronavirus (COVID-19) in China. Current Topics in Medicinal Chemistry.DOI: $10.2174 / 1568026620999200305145032$

79 LiveScience. 2020. First coronavirus vaccine trial in the US is recruiting volunteers. Livescience.com. $\quad$ https://www.livescience.com/us-coronavirus-vaccine-trialrecruiting.html

80 Lu H, Stratton C W and Tang Y W. 2020. Outbreak of Pneumonia of Unknown Etiology in Wuhan China: the Mystery and the Miracle. Journal of Medical Virology 92: 401-02

81 Luo W, Yu H, Gou J, Li X, Sun Y, Li J and Liu L. 2020. Clinical Pathology of Critical Patient with Novel Coronavirus Pneumonia (COVID-19). Pathology \& Pathobiology 2020020407

82 Lv L, Li G, Chen J, Liang X and Li Y. 2020. Comparative genomic analysis revealed specific mutation pattern between human coronavirus SARS-CoV-2 and Bat-SARSrCoV RaTG13. BioRxiv 2020.02.27.969006: 1-20.DOI: 10.1101/2020.02.27.969006

83 Malik Y S, Sircar S, Bhat S, Sharun K, Dhama K, Dadar M, Tiwari R and Chaicumpa W. 2020. Emerging novel Coronavirus (2019-nCoV)-Current scenario, evolutionary perspective based on genome analysis and recent developments. Veterinary Quarterly 40(1): $1-12$

84 Mihindukulasuriya K A, Wu G, Leger J S, Nordhausen R W and Wang D. 2008. Identification of a novel coronavirus from a beluga whale by using a panviral microarray. Journal of Virology 82(10): 5084-88

85 Moderna. 2020. Moderna Announces Funding Award from CEPI to Accelerate Development of Messenger RNA (mRNA) Vaccine Against Novel Coronavirus. Modernatx.com https://investors.modernatx.com/news-releases/news-releasedetails/moderna-announces-funding-award-cepi-accelerate-development.

86 Mohd H A, Al-Tawfiq J A and Memish Z A. 2016. Middle East respiratory syndrome coronavirus (MERS-CoV) origin and animal reservoir. Virology Journal 13(1): 87

87 Monchatre-Leroy E, Boué F, Boucher J-M, Renault C, Moutou F, Ar Gouilh M and Umhang G. 2017. Identification of alpha and beta coronavirus in wildlife species in France: bats, rodents, rabbits, and hedgehogs. Viruses 9(12): 364

88 Mora-Díaz J C, Piñeyro P E, Houston E, Zimmerman J and Giménez-Lirola L G. 2019. Porcine Hemagglutinating Encephalomyelitis Virus: A Review. Frontiers in Veterinary Science 6(53): 1-12 
89 Munjal A, Khandia R, Dhama K, Sachan S, Karthik K, Tiwari R, Malik Y S, Kumar D, Singh R K and Iqbal H. 2017. Advances in developing therapies to combat Zika virus: current knowledge and future perspectives. Frontiers in microbiology 8: 1469

90 Munster V J, Koopmans M, van Doremalen N, van Riel D and de Wit E. 2020. A novel coronavirus emerging in China-key questions for impact assessment. New England Journal of Medicine 382(8): 692-94

91 NIAID. 2020. Developing Therapeutics and Vaccines for Coronaviruses. National Institute of Allergy and Infectious Diseases. https://www.niaid.nih.gov/diseasesconditions/coronaviruses-therapeutics-vaccines.

92 Nishiura H, Linton N M and Akhmetzhanov A R. 2020. Initial cluster of novel coronavirus (2019-nCoV) infections in Wuhan, China is consistent with substantial human-to-human transmission. Journal of Clinical Medicine 9(2): 488

93 OIE. 2020. One Health "at a glance". Office International des Epizooties (OIE): World Organisation for Animal Health. https://www.oie.int/en/for-themedia/onehealth/.

94 Oldham J. 1972. Letter to the editor. . Pig Farming 10: 72-73

95 Paim F C, Bowman A S, Miller L, Feehan B J, Marthaler D, Saif L J and Vlasova A N. 2019. Epidemiology of Deltacoronaviruses $(\delta-\mathrm{CoV})$ and Gammacoronaviruses $(\gamma-$ $\mathrm{CoV}$ ) in Wild Birds in the United States. Viruses 11(10): 897

96 Patel A and Jernigan D B. 2020. Initial public health response and interim clinical guidance for the 2019 novel coronavirus outbreak-United States, December 31, 2019-February 4, 2020. Morbidity and Mortality Weekly Report 69(5): 140

97 Perlman S and Netland J. 2009. Coronaviruses post-SARS: update on replication and pathogenesis. Nature reviews Microbiology 7(6): 439-50

98 Pusterla N, Mapes S, Wademan C, White A, Ball R, Sapp K, Burns P, Ormond C, Butterworth K and Bartol J. 2013. Emerging outbreaks associated with equine coronavirus in adult horses. Veterinary Microbiology 162(1): 228-31

99 Ramadan N and Shaib H. 2019. Middle East respiratory syndrome coronavirus (MERS-CoV): A review. Germs 9(1): 35

100 Ren L-L, Wang Y-M, Wu Z-Q, Xiang Z-C, Guo L, Xu T, Jiang Y-Z, Xiong Y, Li Y-J and Li H. 2020. Identification of a novel coronavirus causing severe pneumonia in human: a descriptive study. Chinese Medical Journal. DOI: 10.1097/CM9.0000000000000722 
101 Rodriguez-Morales A, Tiwari R, Sah R and Dhama K. 2020a. COVID-19, an Emerging Coronavirus Infection: Current Scenario and Recent Developments - An Overview. Journal of Pure and Applied Microbiology 14: 6150

102 Rodriguez-Morales A J, Bonilla-Aldana D K, Balbin-Ramon G J, Rabaan A A, Sah R, Paniz-Mondolfi A, Pagliano P and Esposito S. 2020b. History is repeating itself: probable zoonotic spillover as the cause of the 2019 novel Coronavirus Epidemic. Le Infezioni in Medicina 28(1): 3-5

103 Rodriguez-Morales A J, MacGregor K, Kanagarajah S, Patel D and Schlagenhauf P. 2020c. Going global - Travel and the 2019 novel coronavirus. Travel Medicine and Infectious Disease 33: 101578.10.1016/j.tmaid.2020.101578

104 Rottier P J, Nakamura K, Schellen P, Volders H and Haijema B J. 2005. Acquisition of macrophage tropism during the pathogenesis of feline infectious peritonitis is determined by mutations in the feline coronavirus spike protein. Journal of Virology 79(22): $14122-30$

105 Saif L. 2004. Animal coronaviruses: what can they teach us about the severe acute respiratory syndrome? Revue scientifique et technique-Office international des épizooties 23(2): 643-60

106 Salata C, Calistri A, Parolin C and Palù G. 2019. Coronaviruses: a paradigm of new emerging zoonotic diseases. Pathogens and Disease 77(9): ftaa006

107 Sanz M G, Kwon S, Pusterla N, Gold J R, Bain F and Evermann J. 2019. Evaluation of equine coronavirus fecal shedding among hospitalized horses. Journal of Veterinary Internal Medicine 33(2): 918-22

108 Schalk A. 1931. An apparently new respiratory disease of baby chicks. Journal of the American Veterinary Medical Association 78: 413-23

109 SerumInstitute. 2020. Serum Institute to be ready with coronavirus vaccine by 2022. Serum Institute of India. https://www.seruminstitute.com/news.php.

110 Shanmugaraj B, Siriwattananon K, Wangkanont K and Phoolcharoen W. 2020. Perspectives on monoclonal antibody therapy as potential therapeutic intervention for Coronavirus disease-19 (COVID-19). Asian Pacific Journal of Allergy and Immunology.DOI: 10.12932/ap-200220-0773

111 Singh R K, Dhama K, Chakraborty S, Tiwari R, Natesan S, Khandia R, Munjal A, Vora K S, Latheef S K and Karthik K. 2019. Nipah virus: epidemiology, pathology, immunobiology and advances in diagnosis, vaccine designing and control strategies-a comprehensive review. Veterinary Quarterly 39(1): 26-55 
112 Su S, Wong G, Shi W, Liu J, Lai A C, Zhou J, Liu W, Bi Y and Gao G F. 2016. Epidemiology, genetic recombination, and pathogenesis of coronaviruses. Trends in Microbiology 24(6): 490-502

113 Suzuki T, Otake Y, Uchimoto S, Hasebe A and Goto Y. 2020. Genomic Characterization and Phylogenetic Classification of Bovine Coronaviruses Through Whole Genome Sequence Analysis. Viruses 12(2): 183

114 Szczepanski A, Owczarek K, Bzowska M, Gula K, Drebot I, Ochman M, Maksym B, Rajfur Z, Mitchell J A and Pyrc K. 2019. Canine Respiratory Coronavirus, Bovine Coronavirus, and Human Coronavirus OC43: Receptors and Attachment Factors. Viruses 11(4): 328

115 Tan L, Li Y, He J, Hu Y, Cai X, Liu W, Liu T, Wang J, Li Z and Yuan X. 2020. Epidemic and genetic characterization of porcine epidemic diarrhea virus strains circulating in the regions around Hunan, China, during 2017-2018. Archives of Virology: 1-13

116 Tekes G and Thiel H-J. 2016. Feline coronaviruses: pathogenesis of feline infectious peritonitis. In Advances in Virus Research, pp 193-218. Elsevier.

117 Tian S, Hu W, Niu L, Liu H, Xu H and Xiao S-Y. 2020. Pulmonary Pathology of Early Phase SARS-COV-2 Pneumonia. Pathology \& Pathobiology 2020(2020020220).DOI: 10.20944/preprints202002.0220.v

118 Torres-Medina A, Schlafer D H and Mebus C A. 1985. Rotaviral and coronaviral diarrhea. Veterinary Clinics of North America: Food Animal Practice 1(3): 471-93

119 Wang M, Wu Q, Xu W, Qiao B, Wang J, Zheng H, Jiang S, Mei J, Wu Z, Deng Y, et al. 2020. Clinical diagnosis of 8274 samples with 2019-novel coronavirus in Wuhan. medRxiv: 2020.02.12.20022327.DOI: 10.1101/2020.02.12.20022327

120 Wassenaar T M and Zou Y. 2020. 2019_nCoV: Rapid classification of betacoronaviruses and identification of traditional Chinese medicine as potential origin of zoonotic coronaviruses. Letters in Applied Microbiology: 1-7.DOI: 10.1111/lam.13285

121 Weiss S R and Navas-Martin S. 2005. Coronavirus pathogenesis and the emerging pathogen severe acute respiratory syndrome coronavirus. Microbiology and Molecular Biology Reviews 69(4): 635-64

122 WHO. 2003. Consensus document on the epidemiology of severe acute respiratory syndrome (SARS). In World Health Organization.

123 WHO. 2020. Updated WHO recommendations for international traffic in relation to COVID-19 outbreak. In World Health Organization. 
124 Wilder-Smith A, Chiew C J and Lee V J. 2020. Can we contain the COVID-19 outbreak with the same measures as for SARS? The Lancet. Infectious diseases: S1473-3099(20)30129-8.10.1016/S1473-3099(20)30129-8

125 Wilson M E and Chen L H. 2020. Travellers give wings to novel coronavirus (2019nCoV). Journal of Travel Medicine. DOI: 10.1093/jtm/taaa015

126 Wong A C, Li X, Lau S K and Woo P C. 2019. Global epidemiology of bat coronaviruses. Viruses 11(2): 174

127 Wong M C, Cregeen S J J, Ajami N J and Petrosino J F. 2020. Evidence of recombination in coronaviruses implicating pangolin origins of $\mathrm{nCoV}-2019$. bioRxiv 2020.02.07.939207: 1-9.DOI: $10.1101 / 2020.02 .07 .939207$

128 Woo P C, Lau S K, Bai R, Teng J L, Lee P, Martelli P, Hui S-W and Yuen K-Y. 2012a. Complete genome sequence of a novel picobirnavirus, otarine picobirnavirus, discovered in California sea lions. Journal of Virology 86(11): 6377-78

129 Woo P C, Lau S K, Lam C S, Lau C C, Tsang A K, Lau J H, Bai R, Teng J L, Tsang C C and Wang M. 2012b. Discovery of seven novel Mammalian and avian coronaviruses in the genus deltacoronavirus supports bat coronaviruses as the gene source of alphacoronavirus and betacoronavirus and avian coronaviruses as the gene source of gammacoronavirus and deltacoronavirus. Journal of Virology 86(7): 39954008

130 Woo P C, Lau S K, Lam C S, Tsang A K, Hui S-W, Fan R Y, Martelli P and Yuen KY. 2014. Discovery of a novel bottlenose dolphin coronavirus reveals a distinct species of marine mammal coronavirus in Gammacoronavirus. Journal of Virology 88(2): 1318-31

131 Wood C. 2020. Infections without borders: a new coronavirus in Wuhan, China. British Journal of Nursing 29(3): 166-67

132 Wu A, Yu B, Zhang K, Xu Z, Wu D, He J, Luo J, Luo Y, Yu J and Zheng P. 2020. Transmissible gastroenteritis virus targets Paneth cells to inhibit the self-renewal and differentiation of Lgr5 intestinal stem cells via Notch signaling. Cell Death \& Disease 11(1): $1-16$

133 Xiao K, Zhai J, Feng Y, Zhou N, Zhang X, Zou J-J, Li N, Guo Y, Li X and Shen X. 2020. Isolation and Characterization of 2019-nCoV-like Coronavirus from Malayan Pangolins. bioRxiv 2020.02.17.951335: 1-31. DOI: 10.1101/2020.02.17.951335

134 Xu Y-H, Dong J-H, An W-M, Lv X-Y, Yin X-P, Zhang J-Z, Dong L, Ma X, Zhang H-J and Gao B-L. 2020a. Clinical and computed tomographic imaging features of 
novel coronavirus pneumonia caused by SARS-CoV-2. Journal of Infection. DOI: 10.1016/j.jinf.2020.02.017

$135 \mathrm{Xu}$ Y. 2020. Genetic diversity and potential recombination between ferret coronaviruses from European and American lineages. Journal of Infection 80(3): 35071

136 Xu Z, Shi L, Wang Y, Zhang J, Huang L, Zhang C, Liu S, Zhao P, Liu H and Zhu L. 2020b. Pathological findings of COVID-19 associated with acute respiratory distress syndrome. The Lancet Respiratory Medicine 0(0): 1-3. DOI: 10.1016/S22132600(20)30076-X

137 Yu L, Wu S, Hao X, Li X, Liu X, Ye S, Han H, Dong X, Li X, Li J, et al. 2020. Rapid colorimetric detection of COVID-19 coronavirus using a reverse tran-scriptional loopmediated isothermal amplification (RT-LAMP) diagnostic plat-form: iLACO. medRxiv: 2020.02.20.20025874. DOI: 10.1101/2020.02.20.20025874

138 Zhang N, Wang L, Deng X, Liang R, Su M, He C, Hu L, Su Y, Ren J, Yu F, et al. 2020a. Recent advances in the detection of respiratory virus infection in humans. Journal of Medical Virology 92(4): 408-17.10.1002/jmv.25674

139 Zhang X, Deng T, Lu J, Zhao P, Chen L, Qian M, Guo Y, Qiao H, Xu Y and Wang Y. 2020b. Molecular characterization of variant infectious bronchitis virus in China, 2019: Implications for control programs. Transboundary and Emerging Diseases 00: $1-7$

140 Zhao S, Lin Q, Ran J, Musa S S, Yang G, Wang W, Lou Y, Gao D, Yang L and He D. 2020. Preliminary estimation of the basic reproduction number of novel coronavirus (2019-nCoV) in China, from 2019 to 2020: A data-driven analysis in the early phase of the outbreak. International Journal of Infectious Diseases 92: 214-17

141 Zhou P, Fan H, Lan T, Yang X-L, Shi W-F, Zhang W, Zhu Y, Zhang Y-W, Xie Q-M and Mani S. 2018. Fatal swine acute diarrhoea syndrome caused by an HKU2-related coronavirus of bat origin. Nature 556(7700): 255-58

142 Zhou P, Yang X-L, Wang X-G, Hu B, Zhang L, Zhang W, Si H-R, Zhu Y, Li B and Huang C-L. 2020a. Discovery of a novel coronavirus associated with the recent pneumonia outbreak in humans and its potential bat origin. bioRxiv 2020.01.22.914952: 1-18.DOI: $10.1101 / 2020.01 .22 .914952$

143 Zhou P, Yang X, Wang X, Hu B, Zhang L, Zhang W, Si H, Zhu Y, Li B and Huang C. 2020b. A pneumonia outbreak associated with a new coronavirus of probable bat origin. Nature 579: 270-73 
